\title{
Tamarix dioica (Ghaz) Protective Potential in the Carbon Tetrachloride-Induced Hepatotoxicity Animal Model
}

${ }^{1}$ Sumra Komal, ${ }^{2}$ Aqna Malik, ${ }^{3}$ Naheed Akhtar, ${ }^{4}$ Syed Asif Jahanzeb Kazmi, ${ }^{4}$ Fayyaz Anjum, ${ }^{4}$ Ayesha Rida

${ }^{I}$ Department of Pharmacology, School of Basic Medical Sciences, Zhengzhou University, Zhengzhou, China

${ }^{2}$ Department of Pharmacy, The University of Lahore, Gujrat

${ }^{3}$ Department of Medicine, CMH Institute of Medical Sciences, Bahawalpur

${ }^{4}$ Department of Pharmacology and Therapeutics, CMH Institute of Medical Sciences, Bahawalpur

\begin{abstract}
Introduction: Hepatic diseases remain the leading cause of death worldwide. Despite overall advancements in health care, mortality due to hepatic diseases is constantly growing. More than 2 million people globally are estimated to die each year from liver diseases, and current treatment offers little for its management. Thus, it is essential to find more effective and less toxic pharmaceutical alternatives for the treatment of liver diseases.

Aims \& Objectives: Tamarix dioica, a shrub broadly used in herbal medicine for the treatment and prevention of various diseases. The current study was designed to analyze the hepatoprotective effect of $T$. dioica in BALB/cmice against CCl4-induced acute liver damage.

Place and duration of study: The study was conducted in NIH, Islamabad, Pakistan, for six months in 2016-2017.

Material \& Methods: For in vivo evaluation, the animals $(n=42)$ were randomly divided into seven groups $(n=6)$, three control (i.e. Group, I or normal control, group II or induction control received $0.9 \%$ normal saline orally, and Group III or positive control received silymarin $100 \mathrm{mg} / \mathrm{kg}$ per oral), and four treatment groups (i.e. IV, V,VI and VII were treated with oral T.dioica $200 \mathrm{mg} / \mathrm{kg} / \mathrm{day}, 300 \mathrm{mg} / \mathrm{kg} /$ day methanol extract, $200 \mathrm{mg} / \mathrm{kg} / \mathrm{day}$ and $300 \mathrm{mg} / \mathrm{kg} / \mathrm{day}$ of aqueous extracts respectively for six days, followed by intraperitoneal administration of CCl4 on the seventh day. The blood samples were collected for analysis of LFTs, and hepatic tissue was taken for histological analysis. Data was analyzed using SPSS version 16, one-way ANOVA with Duncan's Multiple Range Test (DMRT).

Results: CCl4 induction in Group 2 resulted in severe hepatic derangement manifested as highly elevated mean LFTs (ALT 7245.56, AST 3292.11, ALP $340.09 \mathrm{U} / \mathrm{L}$, bilirubin $4.64 \mathrm{mg} / \mathrm{dl}$ ) as compared to healthy controls (ALT 38.97, AST 50.20, ALP 57.17 U/L, bilirubin $1.25 \mathrm{mg} / \mathrm{dl}$ : (Group 1) levels $\mathrm{p}<0.001$. Pretreatment with different extracts of T.dioica for 6 days before $\mathrm{CCl} 4$ administration produced varying degrees of hepatoprotection. $300 \mathrm{mg} / \mathrm{kg}$ aqueous extract T.dioica (Group7) prevented damage with maximal hepatoprotection, reduced LFTs (ALT: 339.95, AST: 242.90, ALP: 116.86 U/L, bilirubin: $1.38 \mathrm{mg} / \mathrm{dl}$ ) and normalized liver histology as compared to Group 2 and standard drug silymarin 100mg/kg, (ALT: 6483.23, AST: 2567.69, ALP: 272.19 U/L, bilirubin: $2.84 \mathrm{mg} / \mathrm{dl}:$ Group 3) p $<0.001$. Lesser hepatoprotection was provided by T.dioica aqueous extract 200mg/kg (ALT: 439.93, AST: 367.87, ALP: $180.62 \mathrm{U} / \mathrm{L}$ bilirubin: $1.53 \mathrm{mg} / \mathrm{dl}$ : Group VI) and least by $300 \mathrm{mg} / \mathrm{kg} \& 200 \mathrm{mg} / \mathrm{kg}$ methanolic extracts Groups V \& IV (ALT: 6338.06, 6443.91, AST: 2800.81, 3012.34, ALP: 242, 248 U/L \& bilirubin: $2.82 \& 3.62 \mathrm{mg} / \mathrm{dl}$ ) respectively. Further, no drug-induced toxicity symptoms were observed 24 hours after administration of the high dose oral T. dioica 2000 $\mathrm{mg} / \mathrm{kg} /$ body weight aqueous and methanolic extracts were administered.

Conclusion: Pretreatment with $T$. dioica extracts especially $300 \mathrm{mg} / \mathrm{kg}$ aqueous extract reduced acute CCl4-mediated liver damage, ameliorated histopathological as well as biochemical parameters and was free of toxicity in $2000 \mathrm{mg} / \mathrm{kg} /$ body weight dose in the mice experimental model. $T$. dioica has potential in hepatoprotective drug research.
\end{abstract}

Key words: Tamarix dioica, Hepatoprotective, Silymarin, Carbon tetrachloride

\section{INTRODUCTION}

L regulates the majority of body functions, including detoxification, metabolism, antimicrobial defenses, and immune response whereas, any disturbance in its normal functioning may lead toward serious consequences. ${ }^{1}$ The extensive metabolic capacity of the liver makes it more susceptible to chemicals includes liver injuries. ${ }^{2}$ Carbon tetrachloride (CCl4) is identified as a possible human carcinogen. In animals, it is rapidly absorbed into the systemic circulation via the gastrointestinal tract. ${ }^{3,4} \mathrm{CCl} 4$ administration by inhalation, gastric infusion, and oral bolus gave its peak concentration in fats, liver, kidney, brain, and lung, therefore extensively used to induce experimental hepatopathy. ${ }^{5,6}$ In experimental murine 
models, the cytochrome $\mathrm{P} 4502 \mathrm{E} 1$ is predominantly involved in the bio activation of $\mathrm{CCl} 4$. $^{7}$ Accidental exposure to $\mathrm{CCl} 4$ can cause acute hepatic and renal failure followed by dialysis when exposed to 200 ppm CCl4 for less than 3 hours. ${ }^{8}$ Furthermore, hepatic tumors were observed at higher $\mathrm{CCl} 4$ doses followed by loss of cellular $\mathrm{Ca}^{+2}$ sequestration and disruption of $\mathrm{Ca}^{+2}$ homeostasis with subsequent cell damage. ${ }^{9} \mathrm{CCl} 4$ also stimulates fibrosis by activating nitric oxide (NO), tumor necrosis factor $\alpha(\mathrm{TNF}-\alpha)$, and transforming growth factor (TGF)- $\alpha / \beta$ in the cell and pushes the cell toward apoptosis. ${ }^{10}$ Hepatitis cirrhosis, alcoholic liver disease, hemochromatosis, and hepatomas are some examples of liver diseases and current medical treatments for such hepatic diseases are either too expensive or associated with adverse effects. ${ }^{11}$ Medicinal plants have been used worldwide for their therapeutic purposes since ancient times. Extracts of several medicinal plants show permissible results against various diseases without any critical side effects. ${ }^{12}$ Multiple studies validated the usage of traditional medicine in the management of various diseases. ${ }^{13}$ Tamarix dioica (T. dioica) is a small shrub that belongs to the family Tamaricaceae. ${ }^{14}$ The plant is well-known in ancient and present herbal remedies for its antidiabetic, anti-fungal, anti-infective and antidermatosis, carminative, anti-inflammatory, and diuretic properties. ${ }^{15,16}$ Nonetheless, there are still few clinical studies for the therapeutic effectiveness of $T$. dioica. Keeping in view these facts, the present study is designed to evaluate the hepatoprotective potential of $T$. dioica plant aqueous and methanolic extracts against $\mathrm{CCl} 4$-induced toxicity into $\mathrm{BALB} / \mathrm{c}$ mice.

\section{MATERIAL AND METHODS}

\section{Plant material}

Leaves of $T$. dioica were obtained and identified by the Department of Botany, PMAS-Arid Agricultural University Rawalpindi, Pakistan.

\section{Chemicals and reagents}

Carbon tetrachloride, silymarin, olive oil, methanol, distilled water, serum bilirubin and diagnostic kits (Huma Star 600) of Pharmacopoeia grade were obtained from National Institute of Health (NIH), Islamabad, Pakistan.

\section{Animal selection and maintenance}

$\mathrm{BALB} / \mathrm{c}$ mice body weights $35-45 \mathrm{~g}$ on standard laboratory diet were obtained from NIH Islamabad, Pakistan, and were kept at $25 \pm 1^{\circ} \mathrm{C}$ temperature, the relative humidity of $10 \%$ with normal light and dark schedule. The research proposal was evaluated and approved by Research Ethical Committee and a lot reference number 10-M.PH/LCWU-17981.

\section{Extract preparation}

\section{Tamarix dioica aqueous extract}

Dried $T$. dioica aqueous extraction were prepared by grinding followed by soaking in distilled water $(20 \mathrm{~g} / 200 \mathrm{ml})$ for overnight and then boiled at $100^{\circ} \mathrm{C}$. The extract was cooled at room temperature and supernatant was then filtered through Whatman ${ }^{\circledR}$ Grade 42 filter paper. ${ }^{17}$

\section{Tamarix dioica methanolic extract}

Dried plant material was ground and extracted with $80 \%$ methanol $(20 \mathrm{~g} / 200 \mathrm{ml})$ to obtain the crude methanolic extract. The extract was concentrated by rotary evaporation and stored in the refrigerator at $4^{\circ} \mathrm{C}$ for future study and dose preparation. ${ }^{17}$

\section{Biological Study}

Drug administration protocol and animal grouping

Animals were divided into seven groups $(n=6)$. All groups received standard food orally throughout the study period. Group, I (Normal control or NC) and group II (Induction control) were administered 0.9\% normal saline orally for six days. Group III (Positive control) received silymarin $100 \mathrm{mg} / \mathrm{kg}$ per oral. Two treatment groups (IV and V) were treated with methanol extract (ME), and the other two groups (VI and VII) received aqueous extracts (AE) orally at the dose of 200 and $300 \mathrm{mg} / \mathrm{kg}$ respectively, for six days. All groups, except normal control, received an intraperitoneal injection (i.p.) of $\mathrm{CCl} 4$ in olive oil (1:1) at the dose of $0.5 \mathrm{mg} / \mathrm{kg}$ for hepatotoxicity induction on the seventh day of study.

\section{Acute toxicity studies}

Male mice were selected for the acute toxicity testing according to OECD guidelines-423. ${ }^{18}$ T.dioica aqueous and methanolic extracts at the dose of $2000 \mathrm{mg} / \mathrm{kg}$ body weight were administered p.o while distilled water was given to the control group.

\section{Blood and liver sample collection}

The experimental animals were sacrificed for blood and liver collection. Blood was collected directly from the aorta followed by centrifugation for five minutes at $12000 \mathrm{rpm} / \mathrm{min}$. The supernatant was collected and preserved at $-20^{\circ} \mathrm{C}$ for further analysis. Livers samples were preserved in 10\% formalin solution and stored for subsequent analysis. ${ }^{19}$

\section{Liver biochemical assessment}

Liver function tests (LFTs) including aspartate aminotransferase (AST), alkaline phosphatase (ALP), alanine transaminase (ALT), and total bilirubin were determined via commercially available diagnostic kits (HumaStar 600).

\section{Histopathological observation}

Animal liver samples were obtained for histopathological examination and preserved in 
formalin $(10 \% \mathrm{v} / \mathrm{v})$ solution followed by paraffin embedding and cutting into $5 \mu \mathrm{m}$ thick sections with a microtome and were stained subsequently with hematoxylin and eosin (H\&E) dye and were observed under the light microscope (IM-910 IRMECO GmbH \& Co. Germany).

\section{Statistical analysis:}

Statistical analysis was done by using SPSS software version 16.0, one-way analysis of variance (ANOVA) with Duncan's Multiple Range Test (DMRT). All results were expressed as mean $\pm \mathrm{SE}$ and $5 \%$ level of significance $(\mathrm{P} \leq 0.05)$.

\section{RESULTS}

Effect of $T$. dioica extracts on bilirubin levels against CCl4-induced acute liver injury in BALB/c mice:

The results depicted that the bilirubin levels in the induction group (II) significantly increased, $\mathrm{p}<0.05$, $(4.64 \pm 0.029)$ as compared to the control group $(1.25 \pm 0.018)$. It shows that CCl4 induces hepatotoxicity. The groups that received the pretreatment with $\mathrm{ME}$ and $\mathrm{AE}$ have statistically significant lower levels of bilirubin $(p<0.05)$, as shown in Table-1 and Fig-1.

Effect of $T$. dioica on liver parameters

A significant increase level of AST and ALT ( $\mathrm{p} \leq$ $0.05)$ was observed in the carbon-tetrachloride treated (II) group as compared to the normal control group (Table-1). The ME and AE pretreatment and standard drug treatment have significantly $(p<0.05)$ reduced the upregulated serum liver markers (AST and ALT), which showed the hepatoprotective effects of T. dioica. As shown in Table-2 and Fig-2. Furthermore, among various treatment groups, maximum protection was observed in $\mathrm{AE}$ treated group against $\mathrm{CCl}$-induced acute liver injury. As shown in Table-3 and Fig-3.

Tamarix dioica protects mice from CCl4-induced acute liver injury

Liver histopathological examination showed significant changes on liver section exposed with CCl4 (B) when compared to the control (NC) group (A) shown in Fig-4. The changes in $\mathrm{CCl} 4$ exposed liver section revealed abnormal morphological characteristics, vacuolated hepatocytes, fat accumulation, mitotic figures and the severity of hepatic damage. The histopathological examination of liver sections of standard group (C) showed to have significantly reduced mitotic figures, vacuolated hepatocytes and no fat accumulation. The pretreated mice groups with AE (D: $200 \mathrm{mg} / \mathrm{kg}$ \& E: $300 \mathrm{mg} / \mathrm{kg}$ ) and $\mathrm{ME}(\mathrm{F}: 200 \mathrm{mg} / \mathrm{kg}$ \& $\mathrm{G}$ : $300 \mathrm{mg} / \mathrm{kg}$ ) found to have significantly organized liver tissues, highly significant lower fat accumulation and vacuolated hepatic cells as compared to $\mathrm{CCl} 4$ exposed (B) group. The animal group treated with $\mathrm{AE} 300 \mathrm{mg} / \mathrm{kg}$ showed to have maximum liver protection. Furthermore, no toxicity symptoms were observed after 24 hours when a high dose of $2000 \mathrm{mg} / \mathrm{kg}$ body weight of $T$. dioica aqueous and methanolic extracts was administered p.o. compare to the control group.

\begin{tabular}{|c|c|c|c|c|}
\hline \begin{tabular}{|c|} 
Serum \\
Parameters \\
$(\mathrm{U} / \mathrm{L})$ \\
\end{tabular} & ALP & ALT & AST & $\begin{array}{c}\text { Total } \\
\text { Bilirubin } \\
(\mathrm{mg} / \mathrm{dl}) \\
\end{array}$ \\
\hline $\begin{array}{c}\text { NC } \\
\text { (Group I) }\end{array}$ & $\begin{array}{c}57.17 \pm \\
0.731 \\
\end{array}$ & $\begin{array}{c}38.97 \pm \\
0.54\end{array}$ & $\begin{array}{c}50.20 \pm \\
0.69\end{array}$ & $\begin{array}{l}1.25 \pm \\
0.018\end{array}$ \\
\hline \begin{tabular}{|c|}
$\begin{array}{c}\text { Induction } \\
\text { Control } \\
\text { (Group II) }\end{array}$ \\
\end{tabular} & $\begin{array}{c}340.09 \pm \\
5.709\end{array}$ & $\begin{array}{c}7245.56 \pm \\
84.40\end{array}$ & $\begin{array}{c}3292.11 \pm \\
38.51\end{array}$ & $\begin{array}{c}4.64 \pm \\
0.029 \\
\end{array}$ \\
\hline \begin{tabular}{|c|} 
Positive \\
Control \\
(Group III) \\
\end{tabular} & $\begin{array}{c}272.19 \pm \\
3.386\end{array}$ & $\begin{array}{c}6483.23 \pm \\
28.24\end{array}$ & $\begin{array}{c}2567.69 \pm \\
28.29\end{array}$ & $2.84 \pm 0.13$ \\
\hline \begin{tabular}{|l} 
Treatment- \\
ME 200 \\
(Group IV) \\
\end{tabular} & $\begin{array}{l}248 \pm \\
3.396\end{array}$ & $\begin{array}{c}6443.91 \pm \\
36.74\end{array}$ & $\begin{array}{c}3012.34 \pm \\
36.40\end{array}$ & $\begin{array}{l}3.62 \pm \\
0.094\end{array}$ \\
\hline \begin{tabular}{|c|} 
Treatment - \\
ME 300 \\
$($ Group V)
\end{tabular} & $\begin{array}{l}242 \pm \\
3.715\end{array}$ & $\begin{array}{c}6338.06 \pm \\
44.64\end{array}$ & $\begin{array}{c}2800.81 \pm \\
29.58\end{array}$ & $\begin{array}{c}2.82 \pm \\
0.133\end{array}$ \\
\hline \begin{tabular}{|c|} 
Treatment- \\
AE 200 \\
(Group VI) \\
\end{tabular} & $\begin{array}{c}180.62 \pm \\
5.349\end{array}$ & $\begin{array}{c}439.93 \pm \\
0.86\end{array}$ & $\begin{array}{c}367.87 \pm \\
7.54\end{array}$ & $\begin{array}{l}1.53 \pm \\
0.039\end{array}$ \\
\hline \begin{tabular}{|c|} 
Treatment- \\
AE 300 \\
(Group VII)
\end{tabular} & $\begin{array}{c}116.86 \pm \\
2.681\end{array}$ & $\begin{array}{c}339.95 \pm \\
2.91\end{array}$ & $\begin{array}{c}242.90 \pm \\
3.49\end{array}$ & $\begin{array}{l}1.38 \pm \\
0.109\end{array}$ \\
\hline
\end{tabular}

Table-1: Effect of silymarin and $T$. dioica pretreatment at seventh day on liver function tests of $\mathrm{CCl} 4$ intoxicated mice

\begin{tabular}{|c|c|c|c|c|c|}
\hline $\begin{array}{c}\text { Serum } \\
\text { Parameters } \\
\text { (U/L) }\end{array}$ & $\begin{array}{c}\text { Positive } \\
\text { Control }\end{array}$ & $\begin{array}{c}\text { Treatment } \\
\text { ME 200 }\end{array}$ & $\begin{array}{c}\text { Treatment- } \\
\text { ME 300 }\end{array}$ & Treatment & Areatment- \\
\hline ALP & $20.40 \%$ & $40.13 \%$ & $43.47 \%$ & $18.98 \%$ & $93.13 \%$ \\
\hline ALT & $98.33 \%$ & $85.62 \%$ & $82.21 \%$ & $99.07 \%$ & $100 \%$ \\
\hline AST & $96.29 \%$ & $93.34 \%$ & $91.98 \%$ & $94.21 \%$ & $98.89 \%$ \\
\hline $\begin{array}{c}\text { Total } \\
\text { Bilirubin } \\
\text { (mg/d) }\end{array}$ & $100 \%$ & $89.65 \%$ & $68.96 \%$ & $93.1 \%$ & $75.86 \%$ \\
\hline
\end{tabular}

Table-2: Percentage protection after $T$. dioica extracts pretreatment compares to the standard treatment group

\begin{tabular}{|c|c|}
\hline Treatment groups & Percentage protection \\
\hline $\begin{array}{c}\text { Silymarin } \\
(\mathbf{1 0 0} \mathbf{m g} / \mathbf{k g})+\mathbf{C C l}_{4}\end{array}$ & $78.75 \%$ \\
\hline $\begin{array}{c}\text { Methanolic extract } \\
\text { (200mg/kg) + CCl }\end{array}$ & $77.2 \%$ \\
\hline $\begin{array}{c}\text { Methanolic extract } \\
\text { (300mg/kg) }+\mathbf{C C l}_{4}\end{array}$ & $71.65 \%$ \\
\hline $\begin{array}{c}\text { Aqueous extract (200mg/kg) } \\
+\mathbf{C C l}_{4}\end{array}$ & $76.34 \%$ \\
\hline $\begin{array}{c}\text { Aqueous extract (300mg/kg) } \\
+\mathbf{C C l}_{4}\end{array}$ & $91.97 \%$ \\
\hline
\end{tabular}

Table-3: Percentage protection of silymarin and $T$. dioica leaves extracts against CCl4-induced liver injury 


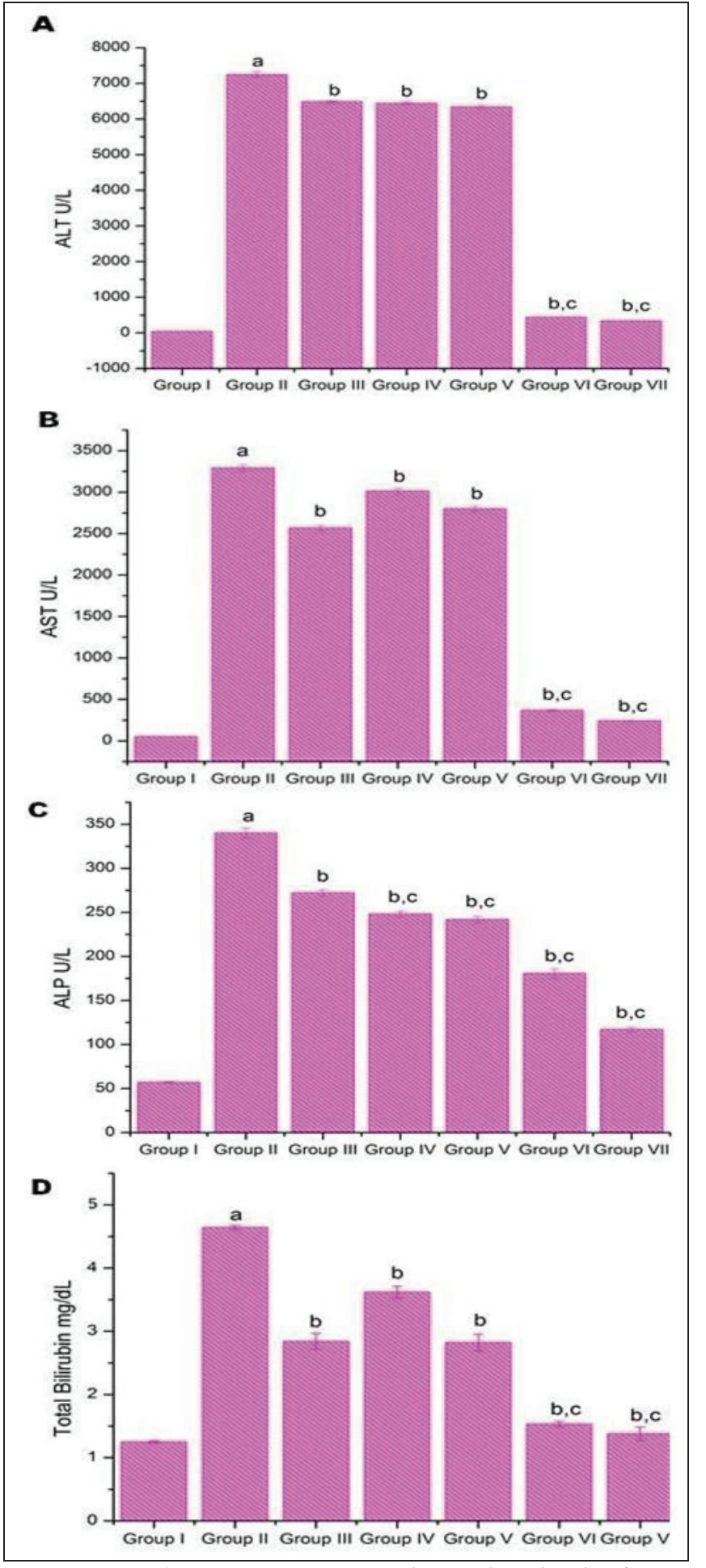

Fig-1: T. dioica protects experimental animals from CCl4-induced liver damage and significantly alters the level of serum biomarkers in treatment groups.

Pretreatment with AE of $T$. dioica $(300 \mathrm{mg} / \mathrm{kg} /$ day p.o) for six days prior to CCl4 exposure $(0.5 \mathrm{mg} / \mathrm{kg})$ on seventh day significantly protects hepatocytes in $\mathrm{Balb} / \mathrm{c}$ mice $(\mathrm{n}=6)$ from liver injury due to the $\mathrm{CCl} 4$ as assessed by measuring (A) serum ALT, (B) AST, (C) ALP, and (D) total bilirubin activity. Each value represents mean \pm S.E.M. $(n=6)$ at $\mathrm{p}<0.001$.
${ }^{\mathrm{a}} \mathrm{p}<0.001$ as compared to group I (normal control). ${ }^{b} \mathrm{p}<0.001$ as compared to group II (induction control). ${ }^{c} p<0.001$ as compared to group III (positive control).

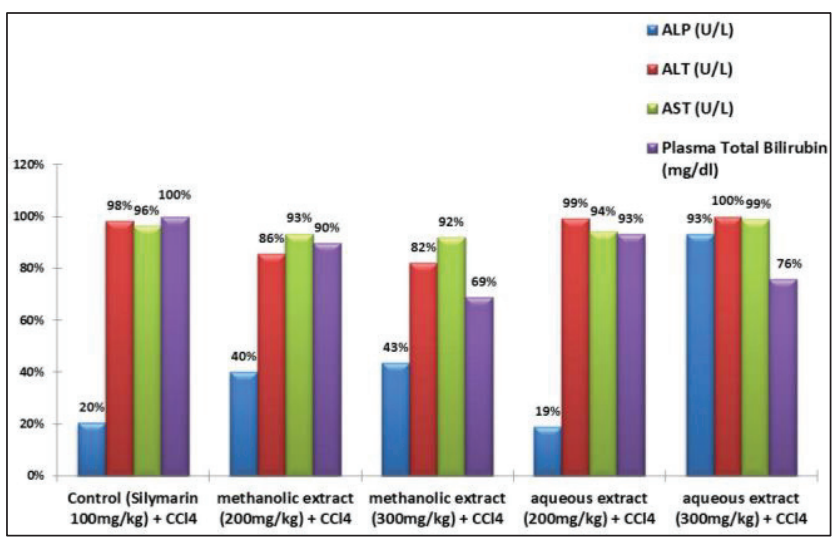

Fig-2: Percentage protection of various biochemical parameters against $\mathrm{CCl} 4$-induced hepatic injury.

Percentage protection of treatment groups, when compared to that of induction control group, revealed that aqueous extract $(300 \mathrm{mg} / \mathrm{kg})$ produced maximum hepatocellular protection as depicted by values of all serum biomarkers.

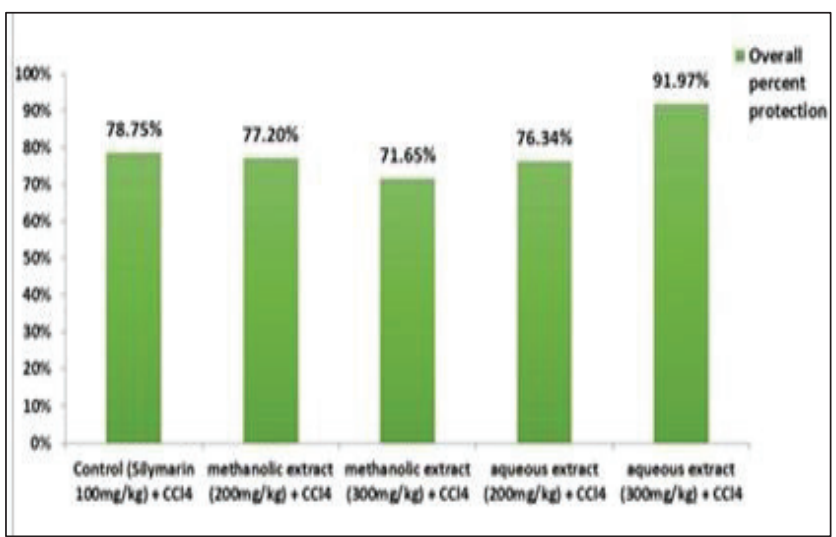

Fig-3: Effects of T. dioica extract on hepatic cells protection

T. dioica aqueous extract $(300 \mathrm{mg} / \mathrm{kg})$ exhibited the maximum overall protection to hepatic cells (91.97 $\%$ ) when compared to the positive control group (silymarin $100 \mathrm{mg} / \mathrm{kg}$ ) and methanolic extracts (ME200 and ME-300) respectively.

Fig-4 shows; (A) Normal cells, (B) CCl4-induced cells, (C) Standard or silymarin-induced cells (200 $\mathrm{mg} / \mathrm{kg}$ ), (D) ME-200 + CCl4 treated cell, (E) ME$300+\mathrm{CCl} 4$ treated cell, (F) AE-200+ CCl4 treated cell, (G) AE-300+ CCl4 treated cell. These results show that pretreatment with $T$. dioica methanolic (D\& E) and aqueous ( $F \& G$ ) extracts significantly protects the hepatic cells from injury compared to silymarin (C) and CCl4-induce (B) groups. 


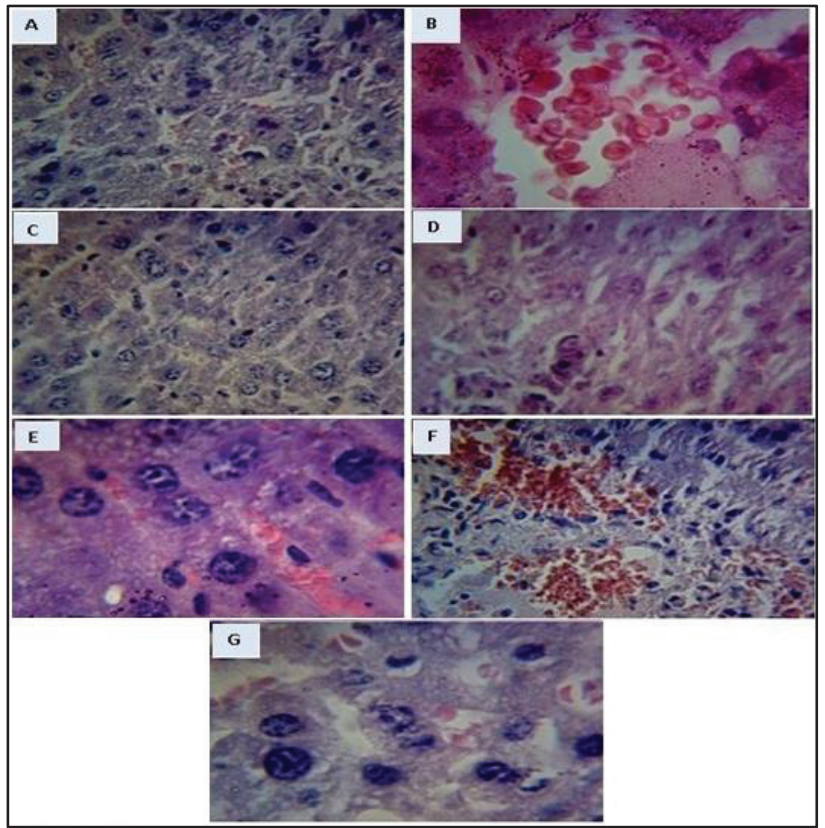

Fig-4: Histopathological examination of liver samples collected from BALB/c mice.

\section{DISCUSSION}

Medicinal plants are the most important source of traditional medicine for the majority of the world's population. Natural products have attracted more attention in the last 20 years as potential sources of new antibacterial, antiviral, and phytotoxic chemicals. ${ }^{20} T$. dioica requires significant attention due to its biological activities. Previous studies on $T$. dioica phytochemical screening showed that steroids and phlobatannins are present in all parts of the plant, while phenols, flavonoids, and tannins, are present in leaves, flowers, and roots; saponins and terpenoids are present in flowers, leaves, and stems. ${ }^{21}$ Studies revealed that plants that contains the highest contents of phenols and flavonoids, are enriched in antioxidants and exhibits their hepatoprotection action against $\mathrm{CCl} 4$-induced liver injuries by inhibiting NF-кB, TNF- $\alpha$, and TGF- $\alpha / \beta$ signaling pathways. $^{22,23}$ Previous studies on phytochemicals screening of $T$. dioica have revealed its strong antiallergic, anti-inflammatory, anticarcinogenic, antiviral, antithrombotic, and hepatoprotective, as well as antioxidant potential. ${ }^{24}$. However, its antioxidant and anti-inflammatory potential supports our findings. ${ }^{25}$ The present study on liver-protective action showed that $T$. dioica leaves extracts, both aqueous and methanolic have given promising results against $\mathrm{CCl} 4$-induced livers injury in mice and shown relatively great improvement than silymarin. The antihepatotoxic effects of Silybum marianum have been studied several times. ${ }^{26} T$. dioica aqueous and methanolic extracts have found non-toxic when administered orally to the animals. ${ }^{27,28}$ Animals pretreatment with Trichosantes dioica aqueous and methanolic extracts exhibit marked improvement against $\mathrm{CCl} 4$-induced hepatotoxicity and also shows significant hepatoprotective effect against $\mathrm{CCl} 4$ toxicity in contrast with silymarin. ${ }^{29}$ A significantly raised $(p<0.005)$ serum level of AST, ALP, ALT, and total bilirubin were observed in $\mathrm{CCl} 4$ treated animals (Group II) as compared to the group treated with standard drug or silymarin (Group III). ${ }^{30}$ In our study the animal receiving aqueous and methanolic extracts of $T$. dioica (Group IV and VII) show a significant reduction in serum markers levels as a comparison to diseased control. The study further confirms that the administration of $T$. dioica extracts at the dose of $200 \mathrm{mg} / \mathrm{kg}, 300 \mathrm{mg} / \mathrm{kg}$ revert the level of serum enzymes towards normal. $T$. dioica aqueous extracts at the dose of $300 \mathrm{mg} / \mathrm{kg}$ show efficient therapeutic effects that are comparable to the standard drug silymarin. No comparative data to support or refute our findings regarding $T$. dioica efficacy against $\mathrm{CCl} 4$ were found. Moreover, no drug-induced toxicity symptoms were observed when a high dose of $2000 \mathrm{mg} / \mathrm{kg}$ body weight of $T$. dioica aqueous and methanolic extracts were administered p.o. Hence, the study revealed that $T$. dioica extracts are safe and have the potential for future development of advanced hepatoprotective drugs. ${ }^{31}$

\section{CONCLUSION}

T. dioica extracts reduced acute CCl4-mediated liver damage in vivo and ameliorated the histopathological as well as biochemical parameters in mice. The $T$. dioica has the potential to alleviate the severity of liver damage caused by carbon tetrachloride. Hence, it is concluded that $T$. dioica can be used as supportive therapy for the treatment of drug-induced and other oxidative stress-mediated hepatoxicity in the future.

\section{Acknowledgement:}

We pay our sincere gratitude to research supervisor Prof. Dr. Hafeez Ikram and co-supervisor Prof. Dr. Mobasher Ahmad Butt. We extend endless thanks to our family, colleagues and friends for provision of consistent courage and support.

\section{REFERENCES}

1. You SL, Il JC, Joo WK, Min KL, Sae KK, Jae SC, Hae J L. Hepatoprotective effects of blue 
honeysuckle on CCl4-induced acute liver damaged mice. Food SciNutr. 2018; 7:322-338.

2. Russo TA, Johnson JR. Medical and economic impact of extraintestinal infections due to Escherichia coli: Focus on an increasingly important endemic problem. Microbes Infect. 2003; 5:449-456.

3. Hashem MM, Salama MM, Mohammed FF, Tohamy $\mathrm{AF}$ and El Deeb KS. Metabolic profile and hepatoprotective effect of Aeschynomeneela phroxylon (Guill. \& Perr.). PloS one. 2019; 14: $\mathrm{e} 0210576$.

4. Abenavoli L, Izzo AA., Milic N, Cicala C, Santini A, and Capasso R. Milk thistle (Silybummarianum): A concise overview on its chemistry, pharmacological, and nutraceutical uses in liver diseases. Phytother Res. 2018; 32: 2202-2213.

5. Magdaleno F, Brol, MJ, Schierwagen R, Uschner FE, Zwick M, and Trebicka J. Animal models when examining the gut-liver axis. in the human gut-liveraxis in health and disease Springer Cham.2019;235-64

6. McCollister DD., Beamer WH, Atchison GJ and Spencer HC. The absorption, distribution and elimination of radioactive carbon tetrachloride by monkeys upon exposure to low vapor concentrations. J. Pharmacol. Exp. Ther. 102: 112-124.

7. Benson, J.M., Tibbetts, B.M., Thrall, K.D. and Springer, D.L. Uptake tissue distribution and fate of inhaled carbon tetrachloride: Comparison of rat, mouse, and hamster. Inhal. Toxicol. 2001; 13:207-17

8. Yu C, Wang F, Jin C, Wu X, Chan WK and McKeehan WL. Increased carbon tetrachlorideinduced liver injury and fibrosis in FGFR4-deficient mice. Am J Pathol. 2002; 161: 2003-2010.

9. Teschke R. Liver injury by carbon tetrachloride intoxication in 16 patients treated with forced ventilation to accelerate toxin removal via the lungs: A clinical report. Toxics. 2018; 6: 25.

10. Weber LW, Boll M, Stampfl A. Hepatotoxicity and mechanism of action of haloalkanes: Carbon tetrachloride as a toxicological model. Crit Rev Toxicol. 33; 105-136.

11. Lu B, Xu Y, Xu L, Cong X, Yin L, Li H, and Peng J. Mechanism investigation of dioscin against $\mathrm{CCl} 4-$ induced acute liver damage in mice. Environ Toxicol Pharmacol. 2012; 34: 127-135.

12. Komal S, Kazmi SA, Khan JA, Gilani MM. Antimicrobial activity of Prunella Vulgaris extracts against multi-drug resistant Escherichia Coli from patients of urinary tract infection. Pak J Med Sci. 2018 May-Jun; 34(3): 616-620.

13. Shiha G, Ibrahim A, Helmy A, Sarin SK, Omata M, Kumar A, and Hamid S. Asian-Pacific Association for the Study of the Liver (APASL) consensus guidelines on invasive and non-invasive assessment of hepatic fibrosis: a 2016 update. HepatolInt 2017; 11:1-30.

14. Atanasov AG, Waltenberger B, Pferschy-Wenzig EM, Linder T, Wawrosch C, Uhrin P, and Rollinger JM. Discovery and resupply of pharmacologically active plant-derived natural products: a review. Biotechnol Adv. 2015; 33:1582-1614.

15. Naz N, Hameed M, Wahid A, Arshad M. and Aqeel Ahmad MS. Patterns of ion excretion and survival in two stoloniferous arid zone grasses. Physiol Plant. 2009; 135:185-95.

16. Bahramsoltani R, Kalkhorani M, Zaidi SM, Farzaei MH, Rahimi R. The genus Tamarix: traditional uses, phytochemistry, and pharmacology. J Ethnopharmacol. 2020; 246:112245.

17. Samejo M Q, Sumbul A, Shah S, Memon SB and Chundrigar S. Phytochemical screening of Tamarix dioica Roxb. ex Roch. J Pharm. 2013; 7(2):181-183.

18. Buschmann J. The OECD guidelines for the testing of chemicals and pesticides. Teratogenicity testing. 2013; 947:37-56.

19. Suurbaar, J., Donkor, A. M., Donkor, M., Saeed, M., Alimatu-Sadia, F., \& Samuel, D. F. Effect of methanol extract of anarcardium occidentale (cashew) stem bark on some biochemical parameters of carbon tetrachloride-induced hepatotoxicity in rats. IJPSR. 2018; 9:3689-3695.

20. Samejo MQ, Sumbul A, Shah S, Memon SB, Chundrigar S. Phytochemical screening of Tamarix dioica Roxb. ex Roch. J. Pharm. Res. 2013; 7:181-3.

21. Saijou E, Enomoto Y, Matsuda M, Yuet-Yin Kok C, Akira S, Tanaka M, and Miyajima A. Neutrophils alleviate fibrosis in the CCl4-induced mouse chronic liver injury model. Hepatol Commun. 2018;2:703-17

22. Saijou E, Enomoto Y, Matsuda M, Yuet-Yin Kok C, Akira S, Tanaka M, and Miyajima A. Neutrophils alleviate fibrosis in the CCl4-induced mouse chronic liver injury model. Hepatol Commun. 2018;2:703-17

23. Nipanikar SU, Chitlange SS, Nagore D. Pharmacological evaluation of hepatoprotective activity of ahpl/aytab/0613 tablet in carbon tetrachloride-, ethanol-, and paracetamol-induced hepatotoxicity models in wistar albino rats. Pharmacognosy Res. 2017; (Suppl 1):S41-S47.

24. Rohini MV, Padmini E. Preliminary phytochemical screening of selected medicinal plants of polyherbal formulation. J. Pharmacogn. Phytochem.2016;5:277.

25. Iqbal A, Din SU, Bakht J, Khan IU, Shah Z. Antiinflammatory, anti-pyretic and analgesic activities of Tamarix dioica. Pak. J. Pharm. Sci. 2019;32.

26. Madani H, Talebol hosseini M, Asgary S and Naderi GH. Hepatoprotective activity of Silybum marianum and Cichorium intybus against thioacetamide in rat. Pakistan J Nutr 2008; 7: 172-176.

27. Ezzat MI, Okba MM, Ahmed SH, El-Banna HA, Prince A, Mohamed SO, Ezzat SM. In-depth hepatoprotective mechanistic study of Phyllanthus niruri: In vitro and in vivo studies and its chemical characterization. PloS one. 2020; 15:e0226185.

28. Dutta S, Chakraborty AK, Dey P, Kar P, Guha P, Sen S, Kumar A, Sen A, Chaudhuri TK. Amelioration of $\mathrm{CCl} 4$ induced liver injury in swiss albino mice by antioxidant rich leaf extract of Croton bon plandianus Baill. PLoS One. 2018; 13:e0196411. 
29. Shivhare Y, Singh P, Rajak H, Patil UK, Pawar RS. Antioxidant potential of Trichosanthes dioica Roxb. (fruits) Phcog J. 2010; 2:107-111.

30. Clichici S, Olteanu D, Nagy AL, Oros A, Filip A, Mircea PA. Silymarin inhibits the progression of fibrosis in the early stages of liver injury in CCl4treated rats. J. Med. Food. 2015; 18:290-298.

31. Khan S, Ullah F, Mahmood T. In vitro antimicrobial and cytotoxic activity of Tamarix dioica Roxb. leaves. Turk. J. Biol. 2013; 37:329-35.

\section{The Authors:}

Sumra Komal

Researcher,

Department of Pharmacology,

School of Basic Medical Sciences,

Zhengzhou University, Zhengzhou, China.

Dr. Aqna Malik,

Assistant Professor,

Department of Pharmacology,

The University of Lahore, Gujrat Campus.
Dr. Naheed Akhtar

Assistant Professor,

Department of Medicine,

CMH Institute of Medical Sciences, Bahawalpur.

Prof. Syed Asif Jahanzeb Kazmi

HOD, Pharmacology and Therapeutics,

CMH Institute of Medical Sciences, Bahawalpur.

Fayyaz Anjum

Lecturer,

Department of Pharmacology and Therapeutics,

CMH Institute of Medical Sciences, Bahawalpur.

Ayesha Rida

Lecturer,

Department of Pharmacology and Therapeutics, CMH Institute of Medical Sciences, Bahawalpur.

\section{Corresponding Author:}

Prof. Syed Asif Jahanzeb Kazmi

HOD, Pharmacology and Therapeutics,

$\mathrm{CMH}$ Institute of Medical Sciences, Bahawalpur.

E-mail: drsajk@hotmail.com 